\title{
Lectins: production and practical applications
}

\author{
Sze Kwan Lam • Tzi Bun Ng
}

Received: 22 August 2010 /Revised: 12 September 2010 /Accepted: 12 September 2010 / Published online: 3 October 2010

(C) The Author(s) 2010. This article is published with open access at Springerlink.com

\begin{abstract}
Lectins are proteins found in a diversity of organisms. They possess the ability to agglutinate erythrocytes with known carbohydrate specificity since they have at least one non-catalytic domain that binds reversibly to specific monosaccharides or oligosaccharides. This articles aims to review the production and practical applications of lectins. Lectins are isolated from their natural sources by chromatographic procedures or produced by recombinant DNA technology. The yields of animal lectins are usually low compared with the yields of plant lectins such as legume lectins. Lectins manifest a diversity of activities including antitumor, immunomo dulatory, antifungal, HIV-1 reverse transcriptase inhibitory, and anti-insect activities, which may find practical applications. A small number of lectins demonstrate antibacterial and anti-nematode activities.
\end{abstract}

Keywords Lectins · Hemagglutinins · Production ·

Practical applications

\footnotetext{
S. K. Lam $(\bowtie)$

Division of Respiratory Medicine, Department of Medicine,

Li Ka Shing Faculty of Medicine, The University of Hong Kong,

Hong Kong, China

e-mail: lamszekwan@yahoo.com.hk

T. B. $\mathrm{Ng}(\bowtie)$

School of Biomedical Sciences, Faculty of Medicine,

The Chinese University of Hong Kong, Shatin, New Territories,

Hong Kong, China

e-mail: b021770@mailserv.cuhk.edu.hk
}

\section{Introduction}

"Lectin" comes from the Latin word "legere", which means "to select", by William Boyd in 1954. Lectins have the ability to bind carbohydrates. Nowadays, proteins that can agglutinate red blood cells with known sugar specificity are referred to as "lectins". The name "hemagglutinins" is used when the sugar specificity is unknown.

Lectins and hemagglutinins are proteins/glycoproteins, which have at least one non-catalytic domain that exhibits reversible binding to specific monosaccharides or oligosaccharides. They can bind to the carbohydrate moieties on the surface of erythrocytes and agglutinate the erythrocytes, without altering the properties of the carbohydrates.

Lectins with specific carbohydrate specificity have been purified from various plant tissues and other organisms. They can be classified on the basis of their carbohydrate specificity. They can also be categorized according to the overall structures into merolectins, holoectins, chimerolectins and superlectins, or be grouped into different families (legume lectins, type II ribosome-inactivating proteins, monocot mannose-binding lectins, and other lectins).

The content of lectin varies in different organisms. The high yields of lectins from different sources may facilitate mass production. Application of lectins is possible depending on their properties. The antifungal and anti-insect activities of lectins can be made use of in the control of pathogens. The production of anti-tumor and anti-viral drugs based on lectins may also be feasible.

\section{Production of lectins}

Lectins are found in nature. A large number of lectins or hemagglutinins have been purified from different organisms. 
On the other hand, lectins can be produced by recombinant techniques.

\section{Recombinant lectins}

Lectins can be produced by recombinant techniques. The natural sources and yields of some lectins are summarized in Table 1 . The yields of lectins were very low $(0.1-5 \mathrm{mg} / \mathrm{L}$ culture medium) before the advent of the nineteenth century. Recently, the yield attained is higher (up to $20 \mathrm{mg} / \mathrm{L}$ culture medium).

In order to produce a sizeable quantity of a lectin, e.g., $10 \mathrm{~g}$, large-scale fermentation is the only way. However, a large fermentor in GMP condition is required. The cost of fermentation is high. Escherichia coli is the most popular expression system used. Different strains, e.g., BL21 (DE3) RIL strain and Nova Blue (DE3) strain, were chosen for expression of different lectins. In general, E. coli transformed with expression vectors is grown in sterilized culture medium, e.g., BMGY medium and Luria-Bertani medium, in a fermentor. Antibiotics, e.g., ampicillin, are added to reduce the chances of contamination. Fermentation is carried out in defined $\mathrm{pH}$ value, temperature, optical density at the time of induction, inducer concentration and time of expression. Isopropyl $\beta$-D-thiogalactoside is the most frequently used inducer. After induction, the cells are harvested by centrifugation. Lectins are released from the cells by resuspension in lysis buffer followed by sonication. Further chromatographic steps are required for purification of lectins (Upadhyay et al. 2010; Tateno et al. 2004).

\section{Natural lectins}

Animal lectins

Lectins are found in different animals. However, the yields are usually extremely low (Table 2). Mass purification of animal lectins necessitates bulk quantities of raw materials which make it not feasible.

\section{Mushroom lectins}

Yields of lectins from fresh mushrooms are low, e.g., $2.6 \mathrm{mg}$ from $100 \mathrm{~g}$ of fresh fruiting bodies of Pleurocybella porrigens (Suzuki et al. 2009). In fact, the water content in fresh mushrooms is very high. Dried fruiting bodies of the mushrooms Russula lepida, Pholiota adiposa, and Inocybe umbrinella yielded 39,70 , and $15 \mathrm{mg}$ lectin per $100 \mathrm{~g}$ fruiting bodies, respectively (Zhang et al. 2010, 2009; Zhao et al. 2009). Therefore, production from fresh mushroom is also unpractical.

\section{Plant lectins}

The lectin contents in some parts of plants are higher, e.g., 390 and $75 \mathrm{mg}$ of the purified lectin was recovered from $100 \mathrm{~g}$ Remusatia vivipara tubers (Bhat et al. 2010) and Astragalus mongholicus roots (Yan et al. 2005), respectively. Lectins are also found in seeds. The lectin content in nonlegume plants is low, e.g., $3.3 \mathrm{mg}$ lectin from $100 \mathrm{~g}$ Hibiscus mutabilis seeds (Lam and Ng 2009). Lectins are found in abundance in legume seeds. Phaseolus vulgaris is an herbaceous annual plant grown worldwide for its edible

Table 1 Yields of plant lectins produced by recombinant DNA techniques

\begin{tabular}{|c|c|c|c|}
\hline $\begin{array}{l}\text { Natural source } \\
\text { of lectin }\end{array}$ & $\begin{array}{l}\text { Lectin yield }(\mathrm{mg} / \mathrm{L} \\
\text { culture medium) }\end{array}$ & Genetically modification in cells & Reference \\
\hline $\begin{array}{l}\text { Allium sativum (garlic) } \\
\text { leaf }\end{array}$ & 5 & $\begin{array}{l}\text { cDNA was cloned into NdeI and BamHI restricted plasmid pET19b } \\
\text { and expressed in } E \text {. coli strain BL21 (DE3) cells }\end{array}$ & Upadhyay et al. 2010 \\
\hline $\begin{array}{l}\text { Artocarpus incise } \\
\text { (breadfruit) }\end{array}$ & 16 & cDNA was cloned into the pET- $25 \mathrm{~b}(+)$ and expressed in $E$. coli. & Oliveira et al. 2009 \\
\hline $\begin{array}{l}\text { Artocarpus incise } \\
\text { (breadfruit) }\end{array}$ & $18-20$ & $\begin{array}{l}\text { cDNA was cloned into EcoRI/XbaI restricted plasmid pUC57 } \\
\text { and expressed in } E \text {. Coli }\end{array}$ & Oliveira et al. 2008 \\
\hline Glycine max (Soybean) & 0.1 & $\begin{array}{l}\text { cDNA was cloned NcoI/NdeI/BamHI restricted plasmid PET-3d } \\
\text { and expressed in E. coli strain BL21(DE3)pLysS }\end{array}$ & Adar et al. 1997 \\
\hline $\begin{array}{l}\text { Nicotiana tabacum } \\
\text { (tobacco) leaves }\end{array}$ & 6 & $\begin{array}{l}\text { cDNA was cloned EcoRI/NotI restricted plasmid and expressed } \\
\text { in } E \text {. coli strain top } 10 \mathrm{~F}\end{array}$ & Lannoo et al. 2007 \\
\hline $\begin{array}{l}\text { Oryza sativa (rice) } \\
\text { roots }\end{array}$ & 14.6 & $\begin{array}{l}\text { cDNA was cloned into NdeI/BamHI restricted pET 3D plasmid } \\
\text { and expressed in } E \text {. coli strain BL21 (DE3) cells }\end{array}$ & Branco et al. 2004 \\
\hline Pisum sativum (pea) & $2-5$ & $\begin{array}{l}\text { cDNA was cloned into HindIII/PstI/BamHI restricted plasmid } \\
\text { and expressed in E. coli strain W3110 }\end{array}$ & Stubbs et al. 1986 \\
\hline $\begin{array}{l}\text { Polyporus squamosus } \\
\text { fruiting bodies }\end{array}$ & $4-7$ & $\begin{array}{l}\text { cDNA was cloned into NdeI/BamHI restricted plasmid and expressed } \\
\text { in } E \text {. coli strain Nova Blue (DE3) }\end{array}$ & Tateno et al. 2004 \\
\hline
\end{tabular}


Table 2 Yields of animal lectins obtained by chromatographic isolation from natural sources

\begin{tabular}{|c|c|c|c|}
\hline Natural source & Chromatography for purification & Lectin yield & Reference \\
\hline $\begin{array}{l}\text { Acropora millepora (coral) } \\
\text { plasma fluid }\end{array}$ & Mannose affinity chromatography & $0.7 \mathrm{mg} / 100 \mathrm{ml}$ plasma & Kvennefors et al. 2008 \\
\hline $\begin{array}{l}\text { Aristichthys nobilis (bighead carp) } \\
\text { gills }\end{array}$ & $\begin{array}{l}\text { DEAE-Sepharose, Sephacryl S-200 } \\
\text { and Superdex } 200\end{array}$ & $9.4 \mathrm{mg} / 100 \mathrm{~g}$ & Pan et al. 2010 \\
\hline $\begin{array}{l}\text { Bubalus bubalis (Buffalo) } \\
\text { heart tissue }\end{array}$ & $\begin{array}{l}\text { Ammonium sulfate precipitation } \\
\text { and Sephadex G50 }\end{array}$ & $0.97 \mathrm{mg} / 100 \mathrm{~g}$ & Ashraf et al. 2010 \\
\hline $\begin{array}{l}\text { Holothuria scabra (sea cucumber) } \\
\text { coelomic fluid }\end{array}$ & Ultrafiltration and Phenyl-Sepharose & $1.6 \mathrm{mg} / 100 \mathrm{ml}$ & Gowda et al. 2008 \\
\hline $\begin{array}{l}\text { Macoma birmanica (marine bivalve) } \\
\text { foot muscles }\end{array}$ & $\begin{array}{l}\text { Ammonium sulfate precipitation } \\
\text { and N-acetylglucosamine Sepharose } 4 \mathrm{~B}\end{array}$ & $4.5 \mathrm{mg} / 100 \mathrm{~g}$ & Adhya et al. 2009 \\
\hline Nemopilema nomurai (jellyfish) & SP-Sepharose and BSM-Toyopearl & $0.35 \mu \mathrm{g} / 100 \mathrm{~g}$ & Imamichi and Yokoyama 2010 \\
\hline
\end{tabular}

beans, popular in both dry and green bean forms. The commercial production of beans is well distributed worldwide. There are different varieties, including anasazi bean, black beans, cranberry bean, borlotti beans, pink beans, pinto beans, kidney beans, shell beans, white beans, yellow beans and French beans, etc. Lectins or hemagglutinins have been purified from different varieties of $P$. vulgaris. The lectin contents are low in some varieties and high in other varieties (Table 3 ).

\section{Purification of lectins or hemagglutinins}

Isolation of lectins can be achieved by a combination of different purification techniques. Acids (e.g., acetic acid used by Naeem et al. 2007), organic solvent (e.g., acetone used by Medeiros et al. 2010) or salt (e.g., ammonium sulfate) can be used to precipitate lectins. Various chromatographic methods, including affinity chromatography, ionic exchange chromatography, hydrophobic interaction chromatography, and gel filtration can be utilized. An increase in the number of purification steps usually results in a lower recovery.

In order to produce a large quantity of lectins, the first criterion is a high lectin content in the starting material. The second criterion is the use of a simple purification protocol. Tetrameric escumite lectin was purified by affinity chromatography on a column containing glutaraldehyde membranes from blood group $\mathrm{O}$ erythrocytes. Four isoforms were separated on Mono-S (cation exchanger) (Castillo-Villanueva et al. 2007). Dark red kidney bean hemagglutinin was unadsorbed on DEAE-cellulose but adsorbed on Affi-gel blue gel (Xia and Ng 2006). French bean 35 hemagglutinin with high purity was isolated by chromatography on Blue-Sepharose and Q-Sepharose (Lam and Ng 2010b).

Notwithstanding recombinant lectins can be synthesized, the high cost and low yield are the drawbacks. From the retrospective reports, production of lectins very often relies on chromatographic isolation from plant sources. This is especially so for Phaselous cultivars.

Table 3 Yields of plant lectins obtained by chromatographic isolation from seeds of different Phaseolus cultivars

\begin{tabular}{|c|c|c|c|c|}
\hline Phaseolus cultivar & Chromatography for purification & $\begin{array}{l}\text { Yield } \\
\text { (mg/100 g seed) }\end{array}$ & Sugar specificity & Reference \\
\hline Anasazi bean & Affi-gel blue gel, Mono S and Superdex 200 & 13 & Not found & Sharma et al. 2009 \\
\hline Dark red kidney bean & DEAE-cellulose and Affi-gel blue gel & 107 & Not found & Xia and Ng 2006 \\
\hline Escumite bean & $\begin{array}{l}\text { Affinity chromatography (glutaraldehyzed membranes } \\
\text { from blood group O erythrocytes) }\end{array}$ & $\begin{array}{l}163 \text { (total of } 4 \\
\text { isoforms) }\end{array}$ & $\begin{array}{l}\mathrm{N} \text {-acetyllactosamine- } \\
\text { type glycans }\end{array}$ & $\begin{array}{l}\text { Castillo-Villanueva } \\
\text { et al. } 2007\end{array}$ \\
\hline $\begin{array}{l}\text { Extralong autumn } \\
\text { purple bean }\end{array}$ & $\begin{array}{l}\text { Blue-Sepharose, Q-Sepharose, Mono Q } \\
\text { and Superdex } 75\end{array}$ & 35 & Galactose & Fang et al. 2010 \\
\hline French bean 12 & $\begin{array}{l}\text { SP-Sepharose, Affi-gel blue, Q-Sepharose, } \\
\text { and Superdex } 200\end{array}$ & 4.8 & Not found & Leung et al. 2008 \\
\hline French bean 35 & Blue-Sepharose, Q-Sepharose and Superdex 75 & 1100 & Not found & Lam and $\mathrm{Ng} 2010 \mathrm{~b}$ \\
\hline Red kidney bean & Affi-gel blue gel and CM-Sepharose & 27.5 & $\begin{array}{l}\text { Lactoferrin, ovalbumin, } \\
\text { thyroglobulin }\end{array}$ & Ye et al. 2001 \\
\hline
\end{tabular}




\section{Practical applications}

Lectins-pathogen management strategies

\section{Anti-insect activity of lectins}

Lectins have been suggested as one of the promising agents against insect pests and have been engineered successfully into a variety of crops including wheat, rice, tobacco, and potatoes. This approach could be used as a part of integrated pest management strategies and caveat pest attack.

In general, it seems that large-scale implementation of transgenic insecticidal and herbicide-tolerant plants does not display considerable negative effects on the environment. Moreover, at least some transgenic plants can improve the corresponding environments and human health because their production considerably reduces the load of chemical insecticides and herbicides (Velkov et al. 2005).

Lectins demonstrate anti-insect activity. They increase the mortality or delay the development of insect (Table 4). When incorporated in an artificial diet, Arisaema jacquemontii lectin adversely affected the development of Bactrocera cucurbitae larvae (Kaur et al. 2006a). Arisaema helleborifolium lectin exhibited anti-insect activity towards the second instar larvae of B. cucurbitae (Kaur et al. 2006b). The insecticidal property of lectins may be due to orchestration of enzymatic activity of larvae. After treatment with different lectins, the activity of esterases in larvae was increased whereas the activity of acid phosphatase and alkaline phosphatase decreased.

Galectin-1 treatment of Plutella xylostella larvae brought about disruption of the microvilli and induced abnormalities in these epithelial cells (Chen et al. 2009b). Dioscorea batatas lectin inhibited the emergence of Helicoverpa armigera larvae into adults by avidly binding to larval brush border and peritrophic membrane (Ohizumi et al.
2009). Arum maculatum tuber lectin caused Lipaphis erysimi and Aphis craccivora to succumb, by binding to the gut brush border membrane vesicle proteins (Majumder et al. 2005). Olneya tesota lectin bound to midgut glycoconjugates and microvillae of Zabrotes subfasciatus larvae. Diminished oviposition and a failure of emergence of adult beetles were observed (Lagarda-Diaz et al. 2009). Annona coriacea lectin displayed toxicity in Anagasta kuehniella which apparently resulted from a change in the gut membrane environment and consequent disruption of digestive enzyme recycling mechanisms by binding to midgut proteins (Coelho et al. 2007). Bauhinia monandra leaf lectin produced mortality in Zabrotes subfaciatus and Callosobruchus maculatus when incorporated into an artificial diet. B. monandra leaf lectin produced a $40 \%$ decrement in weight of $A$. kuehniella larvae. B. monandra leaf lectin bound to midgut proteins of the insect $C$. maculatus (Macedo et al. 2007).

The detached leaves from transgenic tobacco plants expressing Allium sativum lectins reduced the weight gain and development and the metamorphosis of Spodoptera littoralis larvae. Furthermore, the larvae were detrimental to the pupal stage resulting in weight reduction and lethal abnormalities (Sadeghi et al. 2008). Production of Rhopalosiphum maidis nymphs was significantly reduced on Galanthus nivalis agglutinin-expressing plants (Wang et al. 2005). G. nivalis agglutinin was also found bound to glycoproteins that can be found in the guts of larvae of Adalia bipunctata, Chrysoperla carnea, and Coccinella septempunctata (Hogervorst et al. 2006).

\section{Antifungal activity of lectins}

Despite the large numbers of lectins and hemagglutinins that have been purified, only a few of them manifested

Table 4 Anti-insect activity of lectins

\begin{tabular}{|c|c|c|c|c|}
\hline Natural source of lectin & Insect affected & Anti-insect effect & Sugar specificity & Reference \\
\hline Allium sativum (garlic) bulbs & $\begin{array}{l}\text { Acyrthosiphon } \\
\text { pisum }\end{array}$ & Increased mortality & Mannose & $\begin{array}{r}\text { Fitches et } \\
\text { al. } 2008\end{array}$ \\
\hline $\begin{array}{l}\text { Arisaema intermedium and } \\
\text { Arisaema wallichianum } \\
\text { (Araceae) }\end{array}$ & $\begin{array}{l}\text { Bactrocera } \\
\text { cucurbitae }\end{array}$ & $\begin{array}{l}\text { (1) Prolonged period of development } \\
\text { (2) Inhibited pupation and emergence }\end{array}$ & Not found & Kaur et al. 2009 \\
\hline Gracilaria cornea (red alga) & $\begin{array}{l}\text { Boophilus } \\
\text { microplus }\end{array}$ & $\begin{array}{l}\text { Reduced (1) the body weight of female after oviposition } \\
\text { period, (2) the egg mass weight, and (3) hatching period }\end{array}$ & $\begin{array}{l}\text { Fetuin, porcine } \\
\text { stomach mucin }\end{array}$ & Lima et al. 2005 \\
\hline Gracilaria ornate (red alga) & $\begin{array}{l}\text { Callosobruchus } \\
\text { maculatus }\end{array}$ & Delayed development & $\begin{array}{l}\text { Fetuin, porcine } \\
\text { stomach mucin }\end{array}$ & Leite et al. 2005 \\
\hline $\begin{array}{l}\text { Myracrodruon urundeuva } \\
\text { (aroeira preta) bark }\end{array}$ & Aedes aegypti & Increased mortality & $\begin{array}{l}\text { N-acetyl-D- } \\
\text { glucosamine }\end{array}$ & Sá et al. 2009 \\
\hline $\begin{array}{l}\text { Xerocomus chrysenteron fruiting } \\
\text { bodies }\end{array}$ & Myzus persicae & Increased mortality & $\begin{array}{l}\text { Fetuin, porcine } \\
\text { stomach mucin }\end{array}$ & Jaber et al. 2008 \\
\hline $\begin{array}{l}\text { Xerocomus chrysenteron fruiting } \\
\text { bodies }\end{array}$ & Myzus persicae & $\begin{array}{l}\text { (1) Increased mortality } \\
\text { (2) Reduction of body weight, duration of development } \\
\text { and fecundity }\end{array}$ & $\begin{array}{l}\text { Fetuin, porcine } \\
\text { stomach mucin }\end{array}$ & Jaber et al. 2007 \\
\hline
\end{tabular}


antifungal activity (Table 5). The expression of Gastrodia elata lectins in the vascular cells of roots and stems was strongly induced by the fungus Trichoderma viride, indicating that lectin is an important defense protein in plants (Sá et al. 2009). Following insertion of the precursor gene of stinging nettle isolectin I into tobacco, the germination of spores of Botrytis cinerea, Colletotrichum lindemuthianum, and T. viride was significantly reduced (Does et al. 1999). Thus, lectins may be introduced into plants to protect them from fungal attack.

Plant lectins can neither bind to glycoconjugates on the fungal membranes nor penetrate the cytoplasm owing to the cell wall barrier. It is not likely lectins directly inhibit fungal growth by modifying fungal membrane structure and/or permeability. However, there may be indirect effects produced by the binding of lectins to carbohydrates on the fungal cell wall surface. Chitinase-free chitin-binding stinging nettle (Urtica dioica lectin) impeded fungal growth. Cell wall synthesis was interrupted because of attenuated chitin synthesis and/or deposition (Van Parijs et al. 1991). The effects of nettle lectin on fungal cell wall and hyphal morphology suggest that the nettle lectin regulates endomycorrhizal colonization of the rhizomes. Several other plant lectins inhibit fungal growth. The first group includes small chitin-binding merolectins with one chitin-binding domain, e.g., hevein from rubber tree latex (Van Parijs et al. 1991) and chitin-binding polypeptide from Amaranthus caudatus seeds (Broekaert et al. 1992). The only plant lectins that can be considered as fungicidal proteins are the chimerolectins belonging to the class I chitinases. However, the antifungal activity of these proteins is ascribed to their catalytic domain.

\section{Lectins-antitumor drugs}

It is well documented that lectins have an antitumor effect. Flammulina velutipes hemagglutinin-inhibited proliferation of leukemia L1210 cells (Ng et al. 2006). Haliclona cratera lectin displayed a cytotoxic effect on HeLa and FemX cells (Pajic et al. 2002). Dark red kidney bean hemagglutinin exerted an antiproliferative activity toward leukemia L1210 cells (Xia and Ng 2006). Small glossy black soybean (Glycine max) lectin impeded proliferation of breast cancer MCF7 cells and hepatoma HepG2 cells (Lin et al. 2008). Del Monte banana lectin retarded proliferation of (L1210) cells and hepatoma (HepG2) cells (Cheung et al. 2009). Extralong autumn purple bean lectin inhibited the proliferation of hepatoma HepG2 cells by inducing the production of apoptotic bodies (Fang et al. 2010). Mistletoe lectin can be

Table 5 Examples of lectins with antifungal activity

\begin{tabular}{|c|c|c|c|}
\hline Natural source of lectin & Fungal species inhibited & Sugar specificity & Reference \\
\hline $\begin{array}{l}\text { Amaranthus viridis } \\
\text { (Green Amaranth) seeds }\end{array}$ & $\begin{array}{l}\text { Botrytis cinerea, Fusarium } \\
\text { oxysporum }\end{array}$ & $\begin{array}{l}\text { Asialofetuin, fetuin, T-antigen, } \\
\text { N-acetyl-D-lactosamine, } \\
\text { N-acetyl-D-galactosamine }\end{array}$ & Kaur et al. 2006c \\
\hline $\begin{array}{l}\text { Astragalus mongholicus } \\
\text { (huangqi) roots }\end{array}$ & $\begin{array}{l}\text { Borrytis cinerea, Colletrichum sp., } \\
\text { Droschslara turia, Fusarium oxysporum }\end{array}$ & D-galactose, lactose & Yan et al. 2005 \\
\hline $\begin{array}{l}\text { Capparis spinosa } \\
\text { (caper) seeds }\end{array}$ & Valsa mali & $\begin{array}{l}\mathrm{D}(+) \text { galactose, } \alpha \text {-lactose, raffinose, } \\
\text { rhamnose, } \mathrm{L}(+) \text {-arabinose, } \mathrm{D}(+) \\
\text { glucosamine }\end{array}$ & Lam et al. 2009 \\
\hline $\begin{array}{l}\text { Capsicum frutescens } \\
\text { (red cluster pepper) seeds }\end{array}$ & $\begin{array}{l}\text { Aspergillus flavus, Fusarium } \\
\text { moniliforme }\end{array}$ & D-mannose, glucose & Ngai and Ng 2007 \\
\hline $\begin{array}{l}\text { Curcuma amarissima Roscoe } \\
\text { (wei ji ku jiang-huang) Rhizomes }\end{array}$ & $\begin{array}{l}\text { Colectrotrichum cassiicola, Exserohilum } \\
\text { turicicum, Fusarium oxysporum }\end{array}$ & Not found & Kheeree et al. 2010 \\
\hline $\begin{array}{l}\text { Dendrobium findlayanum } \\
\text { (orchid) pseudobulbs }\end{array}$ & Alternaria alternata, Colletrichum sp. & Not found & Sattayasai et al. 2009 \\
\hline $\begin{array}{l}\text { Phaselous vulgaris cv } \\
\text { "flageolet bean" seeds }\end{array}$ & Mycosphaerella arachidicola & Not found & Xia and Ng 2005 \\
\hline $\begin{array}{l}\text { Phaselous vulgaris cv } \\
\text { "French bean } 35 \text { " seeds }\end{array}$ & Valsa mali & Not found & Lam and $\mathrm{Ng} 2010 \mathrm{~b}$ \\
\hline Phaseolus coccineus seeds & $\begin{array}{l}\text { Gibberalla sanbinetti, Helminthosporium } \\
\text { maydis, Rhizoctonia solani, Sclerotinia } \\
\text { sclerotiorum }\end{array}$ & Sialic acid & Chen et al. 2009a \\
\hline $\begin{array}{l}\text { Phaseolus vulgaris cv } \\
\text { "red kidney bean" seeds }\end{array}$ & $\begin{array}{l}\text { Coprinus comatus, Fusarium oxysporum, } \\
\text { Rhizoctonia solani }\end{array}$ & $\begin{array}{l}\text { Lactoferrin, ovalbumin, } \\
\text { thyroglobulin }\end{array}$ & Ye et al. 2001 \\
\hline $\begin{array}{l}\text { Pouteria torta } \\
\text { (pouteria trees/eggfruits) seeds }\end{array}$ & $\begin{array}{l}\text { Saccharomyces carevisiae, C. musae, } \\
\text { Fusarium oxysporum }\end{array}$ & $\begin{array}{l}\text { Fetuin, asialofetuin, heparin, } \\
\text { orosomucoid, ovoalbumin }\end{array}$ & Boleti et al. 2007 \\
\hline Talisia esculenta (pitomba) seeds & Microsporum canis & D-mannose & Pinheiro et al. 2009 \\
\hline $\begin{array}{l}\text { Withania somnifera (Ashwagandha/ } \\
\text { Indian ginseng/Winter cherry/ } \\
\text { Ajagandha/Kanaje Hindi/ } \\
\text { Amukkuram) leaves }\end{array}$ & $\begin{array}{l}\text { Fusarium moniliforme, Macrophomina } \\
\text { phaseolina }\end{array}$ & Not found & Ghosh 2009 \\
\hline Zea mays (maize) endosperm & Aspergillus flavus & $\mathrm{D}(+)$ galactose & Baker et al. 2009 \\
\hline
\end{tabular}


used in cancer patients to improve the quality of life (Semiglazov et al. 2006).

In order to widen the application of anti-tumor lectins, the mechanism of action was elucidated. Lectins elicit apoptosis in different cancer cell lines. Examples include Korean mistletoe lectin-treated B16-BL6 melanoma cells (Park et al. 2001), Korean mistletoe lectin-treated human A253 cancer cells (Choi et al. 2004), Agrocybe aegerita lectin-treated HeLa cells (Zhao et al. 2009), Abrus agglutinin-treated Dalton's lymphoma cells (Bhutia et al. 2008a) and HeLa cells (Bhutia et al. 2008b), Sophora flavescens lectin-treated HeLa cells (Liu et al. 2008), Polygonatum odoratum lectintreated murine fibrosarcoma L929 cells (Liu et al. 2009b), Polygonatum cyrtonema lectin-treated human melanoma A375 cells (Liu et al. 2009a), Pseudomonas aeruginosa hemagglutinin-treated breast cancer cells (MDA-MB-468, and MDA-MB-231HM cells; Liu et al. 2009c), French bean hemagglutinin-treated breast cancer MCF-7 cells (Lam and Ng 2010a), and recombinant protease-resistant galectin-9treated myeloma cells (Kobayashi et al. 2010). The apoptotic factors involved are summarized in Table 6.

Although the apoptotic pathways look different, activation of different caspases is usually involved. Caspase-3 plays a central role in apoptosis. It interacts with caspase- 8 and caspase-9. Therefore, caspase-3 is usually investigated in apoptotic pathways, except in the case of a caspase-3- deficient cell line (e.g., MCF-7 cells) which was used in the study of French bean hemagglutinin (Lam and Ng 2010a). Caspase- 8 and -9 are also activated (Liu et al. 2009a; Liu et al. 2009b, c; Kobayashi et al. 2010; Lam and Ng 2010a).

Apoptosis can be mediated by death receptors initated by lectins. FAS receptor is the receptor with which lectins often interact (Liu et al. 2009b, c; Lam and Ng 2010a). The interaction is probably by protein-protein interaction.

The Bcl family members (anti-apoptotic factors) were down-regulated (Bhutia et al. 2008a, b; Liu et al. 2009a; Lam and Ng 2010a). The sequestration of cytochrome $\mathrm{c}$ in mitochondria was interrupted. Cytochrome $\mathrm{c}$ release was observed (Bhutia et al. 2008a, b; Liu et al. 2009a, b; Lam and Ng 2010a). Finally, mitochondrial membrane depolarization was detected (Liu et al. 2009a, b; Lam and Ng 2010a).

G0/G1 arrest was frequently observed (Bhutia et al. 2008a, b; Liu et al. 2009c; Lam and Ng 2010a). It seems that it is the characteristic of lectin-induced apoptosis. Although sub G1 arrest (Park et al. 2001) and G2/M arrest (Lam and Ng 2010a) were found in some cases.

Investigations of the anti-tumor effect of lectin in vivo have been reported. Pleurotus citrinopileatus lectin (Li et al. 2008) and R. lepida lectin (Zhang et al. 2010) exerted potent antitumor activity in white Kunming mice bearing sarcoma 180, and caused inhibition of tumor growth when administered intraperitoneally.

Table 6 Apoptotic modulation of lectin-treated cancer cells

\begin{tabular}{|c|c|c|c|c|c|c|c|c|c|c|c|}
\hline & FAS L & Caspase-9 & Caspase-8 & Caspase-3 & Cytochome c & $\begin{array}{l}\text { Bcl } \\
\text { family }\end{array}$ & $\begin{array}{l}\text { DNA } \\
\text { fragmentation }\end{array}$ & $\begin{array}{l}\text { Morphological } \\
\text { changes }\end{array}$ & Sub G1 & G0/G1 & $\begin{array}{l}\text { Mitochondrial transmembrane } \\
\text { depolarization }\end{array}$ \\
\hline $1^{\mathrm{a}}$ & & & & & & & & + & + & & \\
\hline $2^{\mathrm{b}}$ & & & & + & & & & & & & \\
\hline $3^{c}$ & & & & + & + & + & + & & & + & \\
\hline $4^{\mathrm{d}}$ & & & & + & + & + & + & & & + & \\
\hline $5^{\mathrm{e}}$ & & & + & + & & & + & & & & \\
\hline $6^{\mathrm{f}}$ & + & + & + & + & + & & & & & & + \\
\hline $7^{\mathrm{g}}$ & & + & + & + & + & + & & & & & + \\
\hline $8^{\mathrm{h}}$ & + & + & + & + & & & & & & + & \\
\hline $9^{\mathrm{i}}$ & + & + & + & & + & + & & + & & + & + \\
\hline $10^{\mathrm{j}}$ & & + & + & + & & & & & & & \\
\hline
\end{tabular}

+ Parameter affected by lectin

${ }^{\text {a }}$ Korean mistletoe lectin-treated B16-BL6 melanoma cells (Park et al. 2001)

${ }^{\mathrm{b}}$ Korean mistletoe lectin-treated human A253 cancer cells (Choi et al. 2004)

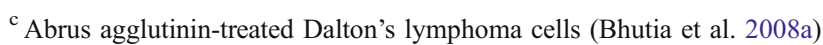

${ }^{\mathrm{d}}$ Abrus agglutinin-treated HeLa cells (Bhutia et al. 2008b)

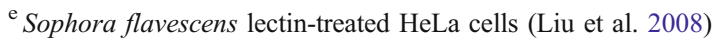

${ }^{\mathrm{f}}$ Polygonatum odoratum-lectin treated murine fibrosarcoma L929 cells (Liu et al. 2009b)

${ }^{g}$ Polygonatum cyrtonema-lectin treated human melanoma A375 cells (Liu et al. 2009a)

${ }^{\mathrm{h}}$ P. aeruginosa hemagglutinin-treated breast cancer cells (MDA-MB-468, and MDA-MB-231HM cells) (Liu et al. 2009c)

${ }^{\mathrm{i}}$ French bean hemagglutinin-treated breast cancer MCF-7 cells (Lam and Ng 2010a)

${ }^{\mathrm{j}}$ Recombinant protease-resistant galectin-9-treated myeloma cells (Kobayashi et al. 2010) 
The aqueous extract of European mistletoe (Viscum album, L.) has been applied in cancer therapy (Lyu et al. 2004). However, in order to make lectin useful practically in the clinical setting, a delivery system is required to lower toxicity, extend exposition, and improve efficacy. Wheat germ agglutinin and Ulex europaeus agglutinin displayed strong interaction with human urinary carcinoma 5,637 cells, which enabled them to target to bladder cancer cells (Plattner et al. 2008). The encapsulation of Cratylia mollis lectin with liposomes lowered its tissue toxicity in the liver and kidney, and improved its antitumor activity in Swiss mice inoculated with sarcoma 180 (Andrade et al. 2004). Mistletoe lectin was stabilized with alginate/chitosan microcapsules coated by a biodegradable polymer wall which can be used to protect the lectin from acidic $\mathrm{pH}$ in the stomach (Lyu et al. 2004).

Immunofluorescence and/or immunohistochemical studies using lectins can reveal the early premalignant stage of prostate carcinogenesis. Expression of glycoconjugates is often altered in tumor cells. Abundant $\mathrm{N}$-acetylglucosamine $(\alpha 1,3) \mathrm{N}$ acetylglucosamine/galactose and galactose $(\beta 1,4) \mathrm{N}$ acetylglucosamine $(\alpha, 2)$ mannose $(\alpha 1,6)$ residues were observed in dysplastic epithelium tumor cells as evidenced by labeling by the $\mathrm{N}$-acetylgalactosamine-specific and complextype oligosaccharide-specific lectins. The binding of these lectins to androgen-independent noble rat prostatic carcinoma was revealed, indicating that these sugar residues are common in some dysplastic and neoplastic prostatic cells (Chan et al. 2001).

\section{Lectins-antiviral drug}

The D-mannose-specific lectin from Gerardia savaglia was firstly reported to prevent infection of $\mathrm{H} 9$ cells with human immunodeficiency virus (HIV)-1. Furthermore, the lectin inhibited syncytium formation in the HTLV-IIIB/H9-Jurkat cell system and HIV-1/human lymphocyte system by reacting with the oligosaccharide side chains of the HIV-1 gp120 envelop molecule (high-mannose oligosaccharides; Müller et al. 1988). A year later, the lectins concanavalin A, wheat germ agglutinin, Lens culinaris agglutinin, Vicia faba agglutinin, Pisum sativum agglutinin and phytohaem (erythro)agglutinin were found to bind to gp120. They were able to inhibit fusion of HIV-infected cells with CD4 cells by a carbohydrate-specific interaction with the HIV-infected cells (Hansen et al. 1989). Plant lectins displayed anti-coronaviral activity, especially mannose-binding lectins, in severe acute respiratory syndrome coronavirus. They interfered viral attachment in early stage of replication cycle and suppressed the growth by interacting at the end of the infectious virus cycle (Keyaerts et al. 2007). Banana (Musa acuminata) lectin inhibited HIV replication (Swanson et al. 2010).

The treatment of AIDS with lectins was further investigated. Different lectins have different anti-HIV mechanisms. More recently, lectin from the polychaete marine worm Chaetopterus variopedatus inhibited cytopathic effect induced by HIV-1 and the production of viral p24 antigen (Wang et al. 2005). The sea worm (Serpula vermicularis) lectin suppressed the production of viral p24 antigen and cytopathic effect induced by HIV-1 (Molchanova et al. 2007). $P$. cyrtonema Hua lectin inhibited HIV-I- and HIV-II-induced cytopathicity in MT-4 and CEM cells (An et al. 2006). Banana lectin directly bound the HIV-1 envelope protein (gp120) and blocked entry of the virus into the cell, and decreased the levels of the strong-stop product of early reverse transcription (Swanson et al. 2010). Extralong autumn purple bean lectin (Fang et al. 2010) and mushroom Russula delica lectin (Zhao et al. 2009) were able to inhibit HIV-1 reverse transcriptase. Hence, lectins are potential drugs for treatment of AIDS.

Besides the aforementioned practical applications of lectins, there have been isolated reports of the antibacterial (Ngai and Ng 2007) and anti-nematode (Wang et al. 2005) activities of lectin.

\section{Other applications}

Lectin affinity chromatography is a form of chromatography in which lectins are immobilized on gel beads. Glycoproteins are then adsorbed by lectins and eluted with a specific carbohydrate. So, it can be employed to fractionate and purify glycoproteins based on their specific features. Moreover, serial lectin column chromatography is useful for isolation of extremely small amounts of glycoproteins. In combination with other separation techniques, oligosaccharides can be purified rapidly.

Eight lectin-Sepharose columns were used to separate different commercial types of recombinant human erythropoietin, erythropoietin analogues and urinary human erythropoietin from healthy individuals (Franco Fraguas et al. 2008). Lectin affinity chromatography, such as immobilized Concanavalin A, was applied in the isolation of glycopeptides that express biantennary and hybrid $\mathrm{N}$-linked structures and highmannose glycans, which are abundant in both embryonic stem cells and embroid bodies stages (Alvarez-Manilla et al. 2010).

The structures of glycoproteins are difficult to analyze because of the linked carbohydrates. Lectin microarray provides a solution. Panels of lectins are immobilized on a single chip in an array format. The fluorescent-tagged samples are hybridized to the array. After analysis of the spots-binding pattern, information on carbohydrate composition of the sample can be obtained, even if the glycosylation of samples is small (Pilobello and Mahal 2007). Most recently, lectin microarray was applied in distinguishing mammalian cells that were infected with the intracellular apicomplexan parasite Cryptosporidium parvum. The cells were probed with fluorescent-labeled lectins. N-acetyl-D-galactosamine binding soybean agglutinin generated the largest signal difference due 
to the over-expression of glycoprotein on the surface of infected cells and the glycoprotein located in the intracellular parasites (Yang et al. 2010).

The carbohydrate specificity of lectins is exploited to recognize samples. The steroid hapten digoxigenin-conjugated lectins enable immunological detection of the structures of the bound lectins. Lectins specifically identifying the terminal sugars are used, thus allowing the carbohydrate chain to be identified. It was used to modify the glycosylation patterns of cell surface glycoconjugates during thymocyte selection processes during postnatal period in mice (Balcan et al. 2008).

Lectins from seeds of Vicia cracca react specifically with human blood group A erythrocytes (Rüdiger 1977). A handful of lectins may be considered as excellent reagents for anti-A, anti-B, anti-N etc., but the anti-A and anti-M antisera are not yet regarded as commercially suitable. Lectin from Dolichus biflorus can be used as anti-A, and lectin from Griffonia simplicifolia as anti-B. Lectin from Vicia graminea is said to be a good typing reagent as anti-N (Khan et al. 2002).

\section{Outlook and perspectives}

Lectins are produced by a myriad of organisms, some of which are phylogenetically remote. Hence, it is not surprising to find that mushroom lectins are very different from plant lectins and animal lectins in amino acid sequence, molecular weight, number of subunits, sugar specificity, thermostability, and $\mathrm{pH}$ stability. Isolectins are produced by some mushrooms, e.g., Tricholoma mongolicum (Wang et al. 1995), some plants, e.g., Narcissus tazetta lectin (Ooi et al. 1998), and some animals, e.g., Conger myriaster (Muramoto et al. 1999). Despite disparity in physicochemical and biochemical characteristics, lectins from different sources essentially exhibit common biological activates that encompass antitumor, immunomodulatory, anti HIV-1 reverse transcriptase inhibitory activities which can be regarded as anti-pathogenic activities. It is likely that different lectins have common intracellular effectors; it is noteworthy that the peptide hormone glucagon and the catecholoamine hormone epinephrine are structurally disparate and have distinct receptors on the hepatocyte membrane and also on the adipocyte membrane. They both stimulate membrane-bound adenylate cyclase and raise the intracellular cyclic AMP level to bring about glycogenolysis (Hadley and Levine 2007). A common signaling pathway may be involved for different lectins. Sometimes different pathways are affected, for instance, in their apoptosis-inducing action (Table 6). Of course, it is reasonable that different signaling pathways are employed for different actions, e.g., antiviral and antitumor actions of a lectin. Just like insulin, the ras-dependent pathway ensues in protein synthesis and cell division. On the other hand, the ras-independent pathway brings about glucose uptake and glycogen synthesis (Hadley and Levine 2007).

Lectins are a subject of intense investigations. As more lectins are isolated and further studies are conducted on the biological activities and mechanisms of action of lectins, the production of lectins can be improved and new applications of lectins can be found.

Acknowledgments The award of a direct grant by the Medicine Panel, CUHK Research Committee is gratefully acknowledged.

Open Access This article is distributed under the terms of the Creative Commons Attribution Noncommercial License which permits any noncommercial use, distribution, and reproduction in any medium, provided the original author(s) and source are credited.

\section{References}

Adar R, Streicher H, Rozenblatt S, Sharon N (1997) Synthesis of soybean agglutinin in bacterial and mammalian cells. Eur J Biochem 249:684-689

Adhya M, Singha B, Chatterjee BP (2009) Purification and characterization of an $\mathrm{N}$-acetylglucosamine specific lectin from marine bivalve Macoma birmanica. Fish Shellfish Immunol 27:1-8

Alvarez-Manilla G, Warren NL, Atwood J 3rd, Orlando R, Dalton S, Pierce M (2010) Glycoproteomic analysis of embryonic stem cells: identification of potential glycobiomarkers using lectin affinity chromatography of glycopeptides. J Proteome Res 9:2062-2075

An J, Liu JZ, Wu CF, Li J, Dai L, Van Damme E, Balzarini J, De Clercq E, Chen F, Bao JK (2006) Anti-HIV I/II activity and molecular cloning of a novel mannose/sialic acid-binding lectin from rhizome of Polygonatum cyrtonema Hua. Acta Biochim Biophys Sin (Shanghai) 38:70-78

Andrade CA, Correia MT, Coelho LC, Nascimento SC, SantosMagalhães NS (2004) Antitumor activity of Cratylia mollis lectin encapsulated into liposomes. Int J Pharm 278:435-445

Ashraf GM, Rizvi S, Naqvi S, Suhail N, Bilal N, Hasan S, Tabish M, Banu $N(2010)$ Purification, characterization, structural analysis and protein chemistry of a buffalo heart galectin-1. Amino Acids (in press)

Baker RL, Brown RL, Chen ZY, Cleveland TE, Fakhoury AM (2009) A maize lectin-like protein with antifungal activity against Aspergillus flavus. J Food Prot 72:120-127

Balcan E, Tuğlu I, Sahin M, Toparlak P (2008) Cell surface glycosylation diversity of embryonic thymic tissues. Acta Histochem 110:14-25

Bhat GG, Shetty KN, Nagre NN, Neekhra VV, Lingaraju S, Bhat RS, Inamdar SR, Suguna K, Swamy BM (2010) Purification, characterization and molecular cloning of a monocot mannosebinding lectin from Remusatia vivipara with nematicidal activity. Glycoconj J 27:309-320

Bhutia SK, Mallick SK, Maiti S, Maiti TK (2008a) Antitumor and proapoptotic effect of Abrus agglutinin derived peptide in Dalton's lymphoma tumor model. Chem Biol Interact 174:11-18

Bhutia SK, Mallick SK, Stevens SM, Prokai L, Vishwanatha JK, Maiti TK (2008b) Induction of mitochondria-dependent apoptosis by Abrus agglutinin derived peptides in human cervical cancer cell. Toxicol In Vitro 22:344-351

Boleti AP, Freire MG, Coelho MB, Silva W, Baldasso PA, Gomes VM, Marangoni S, Novello JC, Macedo ML (2007) Insecticidal and antifungal activity of a protein from Pouteria torta seeds with lectin-like properties. J Agric Food Chem 55:2653-2658 
Branco AT, Bernabé RB, dos Santos FB, de Oliveira MV, Garcia AB, de Souza Filho GA (2004) Expression and purification of the recombinant SALT lectin from rice (Oryza sativa L.). Protein Expr Purif 33:34-38

Broekaert WF, Mariën W, Terras FR, De Bolle MF, Proost P, Van Damme J, Dillen L, Claeys M, Rees SB, Vanderleyden J et al (1992) Antimicrobial peptides from Amaranthus caudatus seeds with sequence homology to the cysteine/glycine-rich domain of chitin-binding proteins. Biochemistry 31:4308-4314

Castillo-Villanueva A, Caballero-Ortega H, Abdullaev-Jafarova F, Garfias Y, del Carmen Jiménez-Martínez M, Bouquelet S, Martínez G, Mendoza-Hernández G, Zenteno E (2007) Lectin from Phaseolus acutifolius var. escumite: chemical characterization, sugar specificity, and effect on human T-lymphocytes. J Agric Food Chem 55:5781-5787

Chan FL, Choi HL, Ho SM (2001) Analysis of glycoconjugate patterns of normal and hormone-induced dysplastic Noble rat prostates, and an androgen-independent Noble rat prostate tumor, by lectin histochemistry and protein blotting. Prostate 46:21-32

Chen J, Liu B, Ji N, Zhou J, Bian HJ, Li CY, Chen F, Bao JK (2009a) A novel sialic acid-specific lectin from Phaseolus coccineus seeds with potent antineoplastic and antifungal activities. Phytomedicine 16:352-360

Chen SJ, Chen NT, Wang SH, Hsu JC, Ding WH, Kuo-Huang LL, Huang RN (2009b) Insecticidal action of mammalian galectin-1 against diamondback moth (Plutella xylostella). Pest Manag Sci 65:923-930

Cheung AH, Wong JH, Ng TB (2009) Musa acuminata (Del Monte banana) lectin is a fructose-binding lectin with cytokine-inducing activity. Phytomedicine 16:594-600

Choi SH, Lyu SY, Park WB (2004) Mistletoe lectin induces apoptosis and telomerase inhibition in human A253 cancer cells through dephosphorylation of Akt. Arch Pharm Res 27:68-76

Coelho MB, Marangoni S, Macedo ML (2007) Insecticidal action of Annona coriacea lectin against the flour moth Anagasta kuehniella and the rice moth Corcyra cephalonica (Lepidoptera: Pyralidae). Comp Biochem Physiol C Toxicol Pharmacol 146:406-414

Does MP, Houterman PM, Dekker HL, Cornelissen BJ (1999) Processing, targeting, and antifungal activity of stinging nettle agglutinin in transgenic tobacco. Plant Physiol 120:421-432

Fang EF, Lin P, Wong JH, Tsao SW, Ng TB (2010) A lectin with antiHIV-1 reverse transcriptase, antitumor, and nitric oxide inducing activities from seeds of Phaseolus vulgaris cv. extralong autumn purple bean. J Agric Food Chem 58:2221-2229

Fitches E, Wiles D, Douglas AE, Hinchliffe G, Audsley N, Gatehouse JA (2008) The insecticidal activity of recombinant garlic lectins towards aphids. Insect Biochem Mol Biol 38:905-915

Franco Fraguas L, Carlsson J, Lönnberg M (2008) Lectin affinity chromatography as a tool to differentiate endogenous and recombinant erythropoietins. J Chromatogr A 1212:82-88

Ghosh M (2009) Purification of a lectin-like antifungal protein from the medicinal herb, Withania somnifera. Fitoterapia 80:91-95

Gowda NM, Goswami U, Khan MI (2008) Purification and characterization of a T-antigen specific lectin from the coelomic fluid of a marine invertebrate, sea cucumber (Holothuria scabra). Fish Shellfish Immunol 24:450-458

Hadley ME, Levine JE (2007) Endocrinology, 6th edn. Upper Saddle River, New Jersey

Hansen JE, Nielsen CM, Nielsen C, Heegaard P, Mathiesen LR, Nielsen JO (1989) Correlation between carbohydrate structures on the envelope glycoprotein gp120 of HIV-1 and HIV-2 and syncytium inhibition with lectins. AIDS 3:635-641

Hogervorst PA, Ferry N, Gatehouse AM, Wäckers FL, Romeis J (2006) Direct effects of snowdrop lectin (GNA) on larvae of three aphid predators and fate of GNA after ingestion. J Insect Physiol 52:614-624
Imamichi Y, Yokoyama Y (2010) Purification, characterization and cDNA cloning of a novel lectin from the jellyfish Nemopilema nomurai. Comp Biochem Physiol B Biochem Mol Biol 156:1218

Jaber K, Francis F, Paquereau L, Fournier D, Haubruge E (2007) Effect of a fungal lectin from Xerocomus chrysenteron (XCL) on the biological parameters of aphids. Commun Agric Appl Biol Sci 72:629-638

Jaber K, Cuartero Diaz G, Haubruge E, Francis F (2008) Investigation of carbohydrate binding property of a fungal lectin from Xerocomus chrysenteron and potential use on Myzus persicae aphid. Commun Agric Appl Biol Sci 73:629-638

Kaur M, Singh K, Rup PJ, Kamboj SS, Saxena AK, Sharma M, Bhagat M, Sood SK, Singh J (2006a) A tuber lectin from Arisaema jacquemontii Blume with anti-insect and antiproliferative properties. J Biochem Mol Biol 39:432-440

Kaur M, Singh K, Rup PJ, Saxena AK, Khan RH, Ashraf MT, Kamboj SS, Singh J (2006b) A tuber lectin from Arisaema helleborifolium Schott with anti-insect activity against melon fruit fly, Bactrocera cucurbitae (Coquillett) and anti-cancer effect on human cancer cell lines. Arch Biochem Biophys 445:156-165

Kaur N, Dhuna V, Kamboj SS, Agrewala JN, Singh J (2006c) A novel antiproliferative and antifungal lectin from Amaranthus viridis Linn seeds. Protein Pept Lett 13:897-905

Kaur M, Singh K, Rup PJ, Kamboj SS, Singh J (2009) Anti-insect potential of lectins from Arisaema species towards Bactrocera cucurbitae. J Environ Biol 30:1019-1023

Keyaerts E, Vijgen L, Pannecouque C, Van Damme E, Peumans W, Egberink H, Balzarini J, Van Ranst M (2007) Plant lectins are potent inhibitors of coronaviruses by interfering with two targets in the viral replication cycle. Antivir Res 75:179-187

Khan F, Khan RH, Sherwani A, Mohmood S, Azfer MA (2002) Lectins as markers for blood grouping. Med Sci Monit 8:293300

Kheeree N, Sangvanich P, Puthong S, Karnchanatat A (2010) Antifungal and antiproliferative activities of lectin from the rhizomes of Curcuma amarissima Roscoe. Appl Biochem Biotechnol 162:912-925

Kobayashi T, Kuroda J, Ashihara E, Oomizu S, Terui Y, Taniyama A, Adachi S, Takagi T, Yamamoto M, Sasaki N, Horiike S, Hatake K, Yamauchi A, Hirashima M, Taniwaki M (2010) Galectin-9 exhibits anti-myeloma activity through JNK and p38 MAP kinase pathways. Leukemia 24:843-850

Kvennefors EC, Leggat W, Hoegh-Guldberg O, Degnan BM, Barnes AC (2008) An ancient and variable mannose-binding lectin from the coral Acropora millepora binds both pathogens and symbionts. Dev Comp Immunol 32:1582-1592

Lagarda-Diaz I, Guzman-Partida AM, Urbano-Hernandez G, OrtegaNieblas MM, Robles-Burgueño MR, Winzerling J, VazquezMoreno L (2009) Insecticidal action of PF2 lectin from Olneya tesota (Palo Fierro) against Zabrotes subfasciatus larvae and midgut glycoconjugate binding. J Agric Food Chem 57:689-694

Lam SK, Ng TB (2009) Novel galactonic acid-binding hexameric lectin from Hibiscus mutabilis seeds with antiproliferative and potent HIV-1 reverse transcriptase inhibitory activities. Acta Biochim Pol 56:649-654

Lam SK, Ng TB (2010a) First report of a haemagglutinin-induced apoptotic pathway in breast cancer cells. Biosci Rep 30:307-317

Lam SK, Ng TB (2010b) Isolation and characterization of a French bean hemagglutinin with antitumor, antifungal, and anti-HIV-1 reverse transcriptase activities and an exceptionally high yield. Phytomedicine 17:457-462

Lam SK, Han QF, Ng TB (2009) Isolation and characterization of a lectin with potentially exploitable activities from caper (Capparis spinosa) seeds. Biosci Rep 29:293-299 
Lannoo N, Vervecken W, Proost P, Rougé P, Van Damme EJ (2007) Expression of the nucleocytoplasmic tobacco lectin in the yeast Pichia pastoris. Protein Expr Purif 53:275-282

Leite YF, Silva LM, Amorim RC, Freire EA, de Melo Jorge DM, Grangeiro TB, Benevides NM (2005) Purification of a lectin from the marine red alga Gracilaria ornata and its effect on the development of the cowpea weevil Callosobruchus maculatus (Coleoptera: Bruchidae). Biochim Biophys Acta 1724:137-145

Leung EH, Wong JH, Ng TB (2008) Concurrent purification of two defense proteins from French bean seeds: a defensin-like antifungal peptide and a hemagglutinin. J Pept Sci 14:349-353

Li YR, Liu QH, Wang HX, Ng TB (2008) A novel lectin with potent antitumor, mitogenic and HIV-1 reverse transcriptase inhibitory activities from the edible mushroom Pleurotus citrinopileatus. Biochim Biophys Acta 1780:51-57

Lima ME, Carneiro ME, Nascimento AE, Grangeiro TB, Holanda ML, Amorim RC, Benevides NM (2005) Purification of a lectin from the marine red alga Gracilaria cornea and its effects on the cattle tick Boophilus microplus (Acari: Ixodidae). J Agric Food Chem 53:6414-6419

Lin P, Ye X, Ng T (2008) Purification of melibiose-binding lectins from two cultivars of Chinese black soybeans. Acta Biochim Biophys Sin (Shanghai) 40:1029-1038

Liu Z, Liu B, Zhang ZT, Zhou TT, Bian HJ, Min MW, Liu YH, Chen J, Bao JK (2008) A mannose-binding lectin from Sophora flavescens induces apoptosis in HeLa cells. Phytomedicine 15:867-875

Liu B, Cheng Y, Bian HJ, Bao JK (2009a) Molecular mechanisms of Polygonatum cyrtonema lectin-induced apoptosis and autophagy in cancer cells. Autophagy 5:253-255

Liu B, Zhang B, Min MW, Bian HJ, Chen LF, Liu Q, Bao JK (2009b) Induction of apoptosis by Polygonatum odoratum lectin and its molecular mechanisms in murine fibrosarcoma L929 cells. Biochim Biophys Acta 1790:840-844

Liu ZB, Hou YF, Di Min-Dong GH, Wu J, Shen ZZ, Shao ZM (2009c) PA-MSHA inhibits proliferation and induces apoptosis through the up-regulation and activation of caspases in the human breast cancer cell lines. J Cell Biochem 108:195-206

Lyu SY, Kwon YJ, Joo HJ, Park WB (2004) Preparation of alginate/ chitosan microcapsules and enteric coated granules of mistletoe lectin. Arch Pharm Res 27:118-126

Macedo ML, das Graças Machado Freire M, da Silva MB, Coelho LC (2007) Insecticidal action of Bauhinia monandra leaf lectin (BmoLL) against Anagasta kuehniella (Lepidoptera: Pyralidae), Zabrotes subfasciatus and Callosobruchus maculatus (Coleoptera: Bruchidae). Comp Biochem Physiol A Mol Integr Physiol $146: 486-498$

Majumder P, Mondal HA, Das S (2005) Insecticidal activity of Arum maculatum tuber lectin and its binding to the glycosylated insect gut receptors. J Agric Food Chem 53:6725-6729

Medeiros DS, Medeiros TL, Ribeiro JK, Monteiro NK, Migliolo L, Uchoa AF, Vasconcelos IM, Oliveira AS, de Sales MP, Santos EA (2010) A lactose specific lectin from the sponge Cinachyrella apion: purification, characterization, $\mathrm{N}$-terminal sequences alignment and agglutinating activity on Leishmania promastigotes. Comp Biochem Physiol B Biochem Mol Biol 155:211-216

Molchanova V, Chikalovets I, Chernikov O, Belogortseva N, Li W, Wang JH, Yang DY, Zheng YT, Lukyanov P (2007) A new lectin from the sea worm Serpula vermicularis: isolation, characterization and anti-HIV activity. Comp Biochem Physiol C Toxicol Pharmacol 145:184-193

Müller WE, Renneisen K, Kreuter MH, Schröder HC, Winkler I (1988) The D-mannose-specific lectin from Gerardia savaglia blocks binding of human immunodeficiency virus type I to H9 cells and human lymphocytes in vitro. J Acquir Immune Defic Syndr 1:453-458
Muramoto K, Kagawa D, Sato T, Ogawa T, Nishida Y, Kamiya H (1999) Functional and structural characterization of multiple galectins from the skin mucus of conger eel, Conger myriaster. Comp Biochem Physiol B Biochem Mol Biol 123:33-45

Naeem A, Haque S, Khan RH (2007) Purification and characterization of a novel beta-D-galactosides-specific lectin from Clitoria ternatea. Protein J 26:403-413

Ng TB, Ngai PH, Xia L (2006) An agglutinin with mitogenic and antiproliferative activities from the mushroom Flammulina velutipes. Mycologia 98:167-171

Ngai PH, Ng TB (2007) A lectin with antifungal and mitogenic activities from red cluster pepper (Capsicum frutescens) seeds. Appl Microbiol Biotechnol 74:366-371

Ohizumi Y, Gaidamashvili M, Ohwada S, Matsuda K, Kominami J, Nakamura-Tsuruta S, Hirabayashi J, Naganuma T, Ogawa T, Muramoto K (2009) Mannose-binding lectin from yam (Dioscorea batatas) tubers with insecticidal properties against Helicoverpa armigera (Lepidoptera: Noctuidae). J Agric Food Chem 57:2896-2902

Oliveira C, Felix W, Moreira RA, Teixeira JA, Domingues L (2008) Expression of frutalin, an alpha-D-galactose-binding jacalinrelated lectin, in the yeast Pichia pastoris. Protein Expr Purif 60:188-193

Oliveira C, Costa S, Teixeira JA, Domingues L (2009) cDNA cloning and functional expression of the alpha-D-galactose-binding lectin frutalin in Escherichia coli. Mol Biotechnol 43:212-220

Ooi LS, Wang H, Ng TB, Ooi VE (1998) Isolation and characterization of a mannose-binding lectin from leaves of the Chinese daffodil Narcissus tazetta. Biochem Cell Biol 76:601-608

Pajic I, Kljajic Z, Dogovic N, Sladic D, Juranic Z, Gasic MJ (2002) A novel lectin from the sponge Haliclona cratera: isolation, characterization and biological activity. Comp Biochem Physiol C Toxicol Pharmacol 132:213-221

Pan S, Tang J, Gu X (2010) Isolation and characterization of a novel fucose-binding lectin from the gill of bighead carp (Aristichthys nobilis). Vet Immunol Immunopathol 133:154-164

Park WB, Lyu SY, Kim JH, Choi SH, Chung HK, Ahn SH, Hong SY, Yoon TJ, Choi MJ (2001) Inhibition of tumor growth and metastasis by Korean mistletoe lectin is associated with apoptosis and antiangiogenesis. Cancer Biother Radiopharm 16:439-447

Pilobello KT, Mahal LK (2007) Lectin microarrays for glycoprotein analysis. Methods Mol Biol 385:193-203

Pinheiro AQ, Melo DF, Macedo LM, Freire MG, Rocha MF, Sidrim JJ, Brilhante RS, Teixeira EH, Campello CC, Pinheiro DC, Lima MG (2009) Antifungal and marker effects of Talisia esculenta lectin on Microsporum canis in vitro. J Appl Microbiol 107:2063-2069

Plattner VE, Wagner M, Ratzinger G, Gabor F, Wirth M (2008) Targeted drug delivery: binding and uptake of plant lectins using human 5637 bladder cancer cells. Eur J Pharm Biopharm 70:572-576

Rüdiger H (1977) Purification and properties of blood-group-specific lectins from Vicia cracca. Eur J Biochem 72:317-322

Sá RA, Santos ND, da Silva CS, Napoleão TH, Gomes FS, Cavada BS, Coelho LC, Navarro DM, Bieber LW, Paiva PM (2009) Larvicidal activity of lectins from Myracrodruon urundeuva on Aedes aegypti. Comp Biochem Physiol C Toxicol Pharmacol 149:300-306

Sadeghi A, Smagghe G, Broeders S, Hernalsteens JP, De Greve H, Peumans WJ, Van Damme EJ (2008) Ectopically expressed leaf and bulb lectins from garlic (Allium sativum L.) protect transgenic tobacco plants against cotton leafworm (Spodoptera littoralis). Transgenic Res 17:9-18

Sattayasai N, Sudmoon R, Nuchadomrong S, Chaveerach A, Kuehnle AR, Mudalige-Jayawickrama RG, Bunyatratchata W (2009) Dendrobium findleyanum agglutinin: production, localization, anti-fungal activity and gene characterization. Plant Cell Rep 28:1243-1252 
Semiglazov VF, Stepula VV, Dudov A, Schnitker J, Mengs U (2006) Quality of life is improved in breast cancer patients by Standardised Mistletoe Extract PS76A2 during chemotherapy and follow-up: a randomised, placebo-controlled, double-blind, multicentre clinical trial. Anticancer Res 26:1519-1529

Sharma A, Ng TB, Wong JH, Lin P (2009) Purification and characterization of a lectin from Phaseolus vulgaris cv. (Anasazi beans). J Biomed Biotechnol 2009:929568

Stubbs ME, Carver JP, Dunn RJ (1986) Production of pea lectin in Escherichia coli. J Biol Chem 261:6141-6144

Suzuki T, Amano Y, Fujita M, Kobayashi Y, Dohra H, Hirai H, Murata T, Usui T, Morita T, Kawagishi H (2009) Purification, characterization, and cDNA cloning of a lectin from the mushroom Pleurocybella porrigens. Biosci Biotechnol Biochem 73:702-709

Swanson MD, Winter HC, Goldstein IJ, Markovitz DM (2010) A lectin isolated from bananas is a potent inhibitor of HIV replication. J Biol Chem 285:8646-8655

Tateno H, Winter HC, Goldstein IJ (2004) Cloning, expression in Escherichia coli and characterization of the recombinant Neu5Acalpha2, 6Galbeta1, 4GlcNAc-specific high-affinity lectin and its mutants from the mushroom polyporus squamosus. Biochem $\mathrm{J}$ 382:667-675

Upadhyay SK, Saurabh S, Rai P, Singh R, Chandrashekar K, Verma PC, Singh PK, Tuli R (2010) SUMO fusion facilitates expression and purification of garlic leaf lectin but modifies some of its properties. J Biotechnol 146:1-8

Van Parijs J, Broekaert WF, Goldstein IJ, Peumans WJ (1991) Hevein: an antifungal protein from rubber-tree (Hevea brasiliensis) latex. Planta 183:258-264

Velkov VV, Medvinsky AB, Sokolov MS, Marchenko AI (2005) Will transgenic plants adversely affect the environment? J Biosci 30:515-548
Wang HX, Ng TB, Liu WK, Ooi VE, Chang ST (1995) Isolation and characterization of two distinct lectins with antiproliferative activity from the cultured mycelium of the edible mushroom Tricholoma mongolicum. Int J Pept Protein Res 46:508-513

Wang Z, Zhang K, Sun X, Tang K, Zhang J (2005) Enhancement of resistance to aphids by introducing the snowdrop lectin gene gna into maize plants. J Biosci 30:627-638

Xia L, Ng TB (2005) An antifungal protein from flageolet beans. Peptides 26:2397-2403

Xia L, Ng TB (2006) A hemagglutinin with mitogenic activity from dark red kidney beans. J Chromatogr B Analyt Technol Biomed Life Sci 844:213-216

Yan Q, Jiang Z, Yang S, Deng W, Han L (2005) A novel homodimeric lectin from Astragalus mongholicus with antifungal activity. Arch Biochem Biophys 442:72-81

Yang YL, Buck GA, Widmer G (2010) Cell sorting-assisted microarray profiling of host cell response to Cryptosporidium parvum infection. Infect Immun 78:1040-1048

Ye XY, Ng TB, Tsang PW, Wang J (2001) Isolation of a homodimeric lectin with antifungal and antiviral activities from red kidney bean (Phaseolus vulgaris) seeds. J Protein Chem 20:367-375

Zhang GQ, Sun J, Wang HX, Ng TB (2009) A novel lectin with antiproliferative activity from the medicinal mushroom Pholiota adiposa. Acta Biochim Pol 56:415-421

Zhang G, Sun J, Wang H, Ng TB (2010) First isolation and characterization of a novel lectin with potent antitumor activity from a Russula mushroom. Phytomedicine 17:775781

Zhao JK, Wang HX, Ng TB (2009) Purification and characterization of a novel lectin from the toxic wild mushroom Inocybe umbrinella. Toxicon 53:360-366 